\title{
OPUNTIA ELATIOR MILL.-ITS PHYTOCHEMISTRY AND PHARMACOLOGICAL PROPERTIES-A REVIEW
}

\author{
SHARADA R. ID, RABINARAYAN ACHARYA \\ Department of Dravyaguna, ITRA, Jamnagar, India \\ Email: dr.shaaradaramesh@gmail.com
}

Received: 19 Oct 2021, Revised and Accepted: 27 Dec 2021

\begin{abstract}
Opuntia elatior Mill. (OE) (Family Cactaceae), commonly recognized as Red Prickly pear, is a plant of varied nutritional and medicinal benefits. The species has been scrutinized for the composition and wide array of pharmacological activities. This review is attempted with an aim to document the updated status of $\mathrm{OE}$ with respect to its phytochemistry and pharmacological actions. The data is collected from the extensive review of literatures from scientific articles, dissertations and books available on various web-based search engines such as Pub-med, Google-scholar and Science direct and few unpublished observations. The fruit is reported to be rich in carbohydrates, flavonoids, phenolics, betalains, vitamin $\mathrm{C}$ and minerals like calcium, magnesium, iron, zinc, copper, and potassium. Extract and the fruit as a whole are reported for anti-oxidant, hematinic, antileukemic, anti-diabetic, analgesic and anti-inflammatory, anti-fertility, broncho-dilatory, mast cell degranulation, radio-protective and anti-arthritic activities. It is reported to be safe for administration in a dose dependent manner. OE is a nutritionally and medicinally important drug with a wide range of traditional and pharmacological applications. There is a vast scope for research on the varied traditional claims of this drug. This review might help for the further research on the species.
\end{abstract}

Keywords: Nagaphani, Opuntia elatior, Phytochemistry, Pharmacology, Red prickly pear

(C) 2022 The Authors. Published by Innovare Academic Sciences Pvt Ltd. This is an open access article under the CC BY license (https://creativecommons.org/licenses/by/4.0/) DOI: https://dx.doi.org/10.22159/ijpps.2022v14i2.43400. Journal homepage: https://innovareacademics.in/journals/index.php/ijpps.

\section{INTRODUCTION}

The global surge in the use of complementary and alternative medicine, over the last few decades, can be attributed to various reasons, including the affordability, availability, and increased demand. The use of indigenous fruits as food and medicine is often an economically inevitable alternative [1]. They are an integral part of many traditions and tribes. Their role as food or medicine is imperative. Yet they are under-utilized. Few of them being Lasoda (Cordia myxa), Ker (Capparis decidua), Phalsa (Grewia subinaequalis), Pilu (Salvadora oleoides), Hathla thor or Cactus pear (Opuntia species), etc [2].

Opuntia elatior Mill. (OE), Cactaceae, is one such nutritionally and medicinally important plant species which grows in arid to semi-arid regions. Native to northern South America, southern Central America and the southern Lesser Antilles, it was introduced to Indonesia, India and South Africa in the 1800s [3]. In India, this plant is found in Punjab, Uttar Pradesh, Madhya Pradesh, Odisha and particularly in Saurashtra region of Gujarat. Morphologically, OE is sub-arborescent or shrubby, 3 meter high or more. Leaves are small, subulate, caduceus. It is a spiny shrub with flattened, articulate fleshy stems. Presence of 2-5 spines in each areole and the color changes in flower at various stages i. e from yellow to pink and finally, bright red are the key feature of its identification from other allied species of Opuntia [4].

The cladodes are used in the treatment of whooping cough, as an antiinfective agent and in the treatment of gastric ulcer. Decoction of the fruit is used as a purgative. The pulp of the pads is used as a dressing for burns, cuts, wounds, and fractures and is believed to decrease pain and promote healing. Glochids from the plant are rubbed into warts and moles [4]. Updating the current literary evidences with scientific validation on such important species is crucial. Hence an attempt has been made to conduct a methodological review on the phytochemistry and pharmacological properties of OE. Extensive data has been obtained by searching various electronic databases with no specific timeline. The present review provides a summary of up-to-date information on phytochemistry and biological activities of $\mathrm{OE}$.

\section{Search strategy}

The data has been obtained by searching electronic databases such as PubMed, Google Scholar and science direct with no specific timeline, using the search words Nagaphani, Opuntia elatior, Hathlo thor, Prickly pear, nopal, phytochemistry, chemical constituents, biological actions, pharmacological properties. A total of 83 articles witnessed through all the web-based search engines. After omitting the repetitions, and the irrelevant data, 40 articles were selected for detailed review. Among them 15 works were related to phytochemistry and 26 related to pharmacology.

\section{Physico-chemical properties}

Methanolic extract offers maximum yield (36.84\%), compared to hexane and distilled water extracts [5]. Lower concentration of Sodium Benzoate and Tartaric acid preserve Betalains more efficiently as compared to higher concentrations and stability in $\mathrm{pH}$ was also observed in both the preservatives. In case of Steviol, Glycyrrhizin, Piperine and Curcumin, Betalains were more efficiently preserved at higher concentrations of preservatives. Preservation of Betalains was recorded maximum at 0.2 gm Tartaric Acid, $0.4 \mathrm{gm}$ Steviol, and 0.8 gm Curcumin [6]. OE from Rajkot region of Gujarat, India possesses more weight, acidity and ascorbic acid concentrations as compared to other districts of Gujarat i. e Junagadh and Anjar [7]. The average weight of unripe fruit and mature fruit was seen to be $9.09 \mathrm{~g}$ and $12.52 \mathrm{~g}$, respectively. Sp. gr, $\mathrm{pH}$, total solid content, viscosity, moisture content, and ash value were found to be $1.0423,5.27,10.83 \%, 5.11$ millipoise, $74.16 \%$ and $3.59 \%$ respectively [8]. Iodine value, Acid value, Saponification value and Unsaponifiable matter of seed oil were 110.95, 1.64, 191.85 and 2.65 respectively. The assessment of fatty acid composition using gas-liquid chromatography showed presence of $15.65 \%$ saturated fatty acids and $84.35 \%$ unsaturated fatty acids. Linoleic acid was the dominating fatty acid followed by oleic and palmitic acids respectively. The oil analysis showed, OE appears to be a potential source of seed oil for industrial utilization [9].

\section{Chemical composition}

Opuntiol (I), C,H,O, (mol. wt. by mass spectrum, 156) contains one methoxyl group (Zeisel) and an alcoholic hydroxyl group. It forms a monoacetate, $\mathrm{C}_{9} \mathrm{H}_{10} \mathrm{O}_{6}(\mathrm{II}), \mathrm{m}$. p. 110-l 11". A closer scrutiny of the UV data indicates that the spectrum of opuntiol is more akin to that of an $\alpha$-rather than a y-pyrone. From biogenetic considerations and 
compatibility with NMR and UV spectra, opuntiol is likely to be 2hydroxymethyl-4-methoxy- $\alpha$-pyrone (I) [10]. [fig. 1] OE contains $47.10 \mathrm{mg} / 100 \mathrm{ml}$ betacyanin which is comparatively higher than the levels in red dragon fruit (Hylocereus polyrhiyus-36.67 mg/100 ml) and beetroot (beta vulgaris- $16.45 \mathrm{mg} / 100 \mathrm{ml}$ ) Maximum absorption value was obtained at a wavelength of $531 \mathrm{~nm}$ [11]. Betalain concentration in $\mathrm{OE}$ was found to be almost half when compared with Beta vulgaris. Also, the concentration in Opuntia ficus indica was relatively lower than that of OE [6]. 14 active compounds were found in ethanolic extract through GCMS analysis [table 1, fig. 2-6] One of the compounds was 5-hydroxymethylfurfural with an unidentified functional group [12]. Betanin was isolated and was obtained as red-purple powder and UV-visible spectra showed intense absorption peaks at $536 \mathrm{~nm}$. The FTIR spectrum of betanin shows distinct peaks 3402, 2934, 1710, 1628, 1514, 1507, 1411, 1260,1034 and $774 \mathrm{~cm}-1$ respectively [13].<smiles>[R3]c1cc(OC)cc(=O)o1</smiles>

$$
\begin{aligned}
I R & =\text { OH } \\
\text { II } R & =\text { OCOCH, } \\
\text { VI } R=H & =H
\end{aligned}
$$<smiles>[R]Cc1occc(=O)c1OC</smiles>

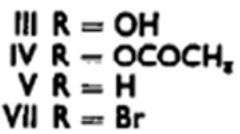

Fig. 1: The IR spectrum of opuntiol had bands at 3395, 1720 , 1700,1640 and $1570 \mathrm{~cm}^{-1}$ and the acetate at 1735, 1720, 1700, 1650 and $1570 \mathrm{~cm}^{-1}$

\begin{tabular}{|c|c|c|c|c|c|}
\hline S. No. & $\begin{array}{l}\text { Retention } \\
\text { time }\end{array}$ & Name of the compound & $\begin{array}{l}\text { Molecular } \\
\text { formula }\end{array}$ & $\begin{array}{l}\text { Molecular } \\
\text { weight }\end{array}$ & $\begin{array}{l}\text { Relative } \\
\text { percentage }\end{array}$ \\
\hline 1 & 3.125 & 2-furancarboxyaldehyde & - & - & 14.7058 \\
\hline 2 & 4.605 & 2,5-Furandione, 3-methyl & $\mathrm{C} 5 \mathrm{H} 403$ & 112 & 12.2549 \\
\hline 3 & 4.864 & 2,5-Furandicarboxaldehyde & $\mathrm{C} 6 \mathrm{H} 403$ & 124 & 3.6764 \\
\hline 4 & 5.099 & 2,3 dihydro, 3,5-dihydroxy 6 methyl $4 \mathrm{H}$ pyran-4-one & - & - & 4.9019 \\
\hline 5 & 5.540 & 2,5-Furandione, dihydro-3-(2-methyl-2-propenyl)- & С8H10O3 & 154 & 2.4509 \\
\hline 6 & 6.192 & Pentanoic acid, 2,2-dimethyl ethyl este & C9H1802 & 158 & 4.9019 \\
\hline 7 & 6.765 & 2-Furancarboxylic acid, 1-methylethyl ester & C8H10O3 & 154 & 6.8627 \\
\hline 8 & 7.226 & Maltol propionate & С9H1004 & 182 & 1.2254 \\
\hline 9 & 7.766 & 4H-Pyran-4-one, 3,5-dichloro2,6-dimethyl & $\mathrm{C} 7 \mathrm{H} 6 \mathrm{Cl} 2 \mathrm{O} 2$ & 192 & 9.8039 \\
\hline 10 & 8.389 & 4H-Pyran-4-one, 5-(acetyloxy)-2(acetyloxy)methyl) & $\mathrm{C} 10 \mathrm{H} 1006$ & 226 & 1.9607 \\
\hline 11 & 8.506 & 2-Tetrazene, 1,1,4,4-tetrakis (1-methylethyl) & C12H28N4 & 228 & 1.4705 \\
\hline 12 & 8.889 & 2-Furancarboxaldehyde, 5-(ethoxymethyl) & $\mathrm{C} 8 \mathrm{H} 10 \mathrm{O} 3$ & 154.06 & 1.4705 \\
\hline 13 & 9.200 & 5-Hydroxy methyl furfural with an unidentified functional group & - & - & 29.4117 \\
\hline 14 & 18.082 & 5,5'-Oxy-Dimethylene-bis (2-Furaldehyde) & $\mathrm{C} 12 \mathrm{H} 1005$ & 234.05 & 4.9019 \\
\hline
\end{tabular}

Table 1: Components detected in the whole fruit of $\mathrm{OE}$
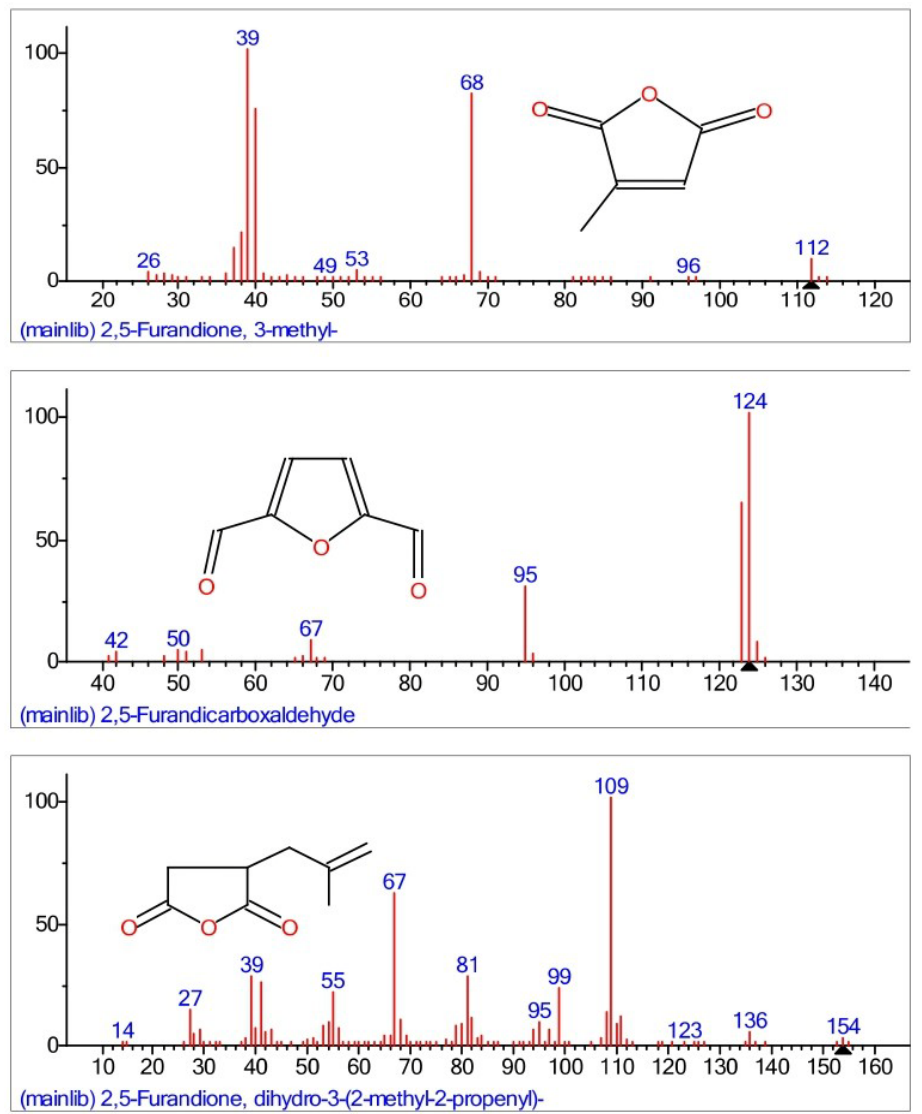

Fig. 2: 2(a), (b), (c): Mass spectrum of 2,5-Furandione, 3-methy (2a), 2,5-Furandicarboxaldehyde (2b), 2,5-Furandione, dihydro-3-(2methyl-2-propenyl)-(2c) [12] 

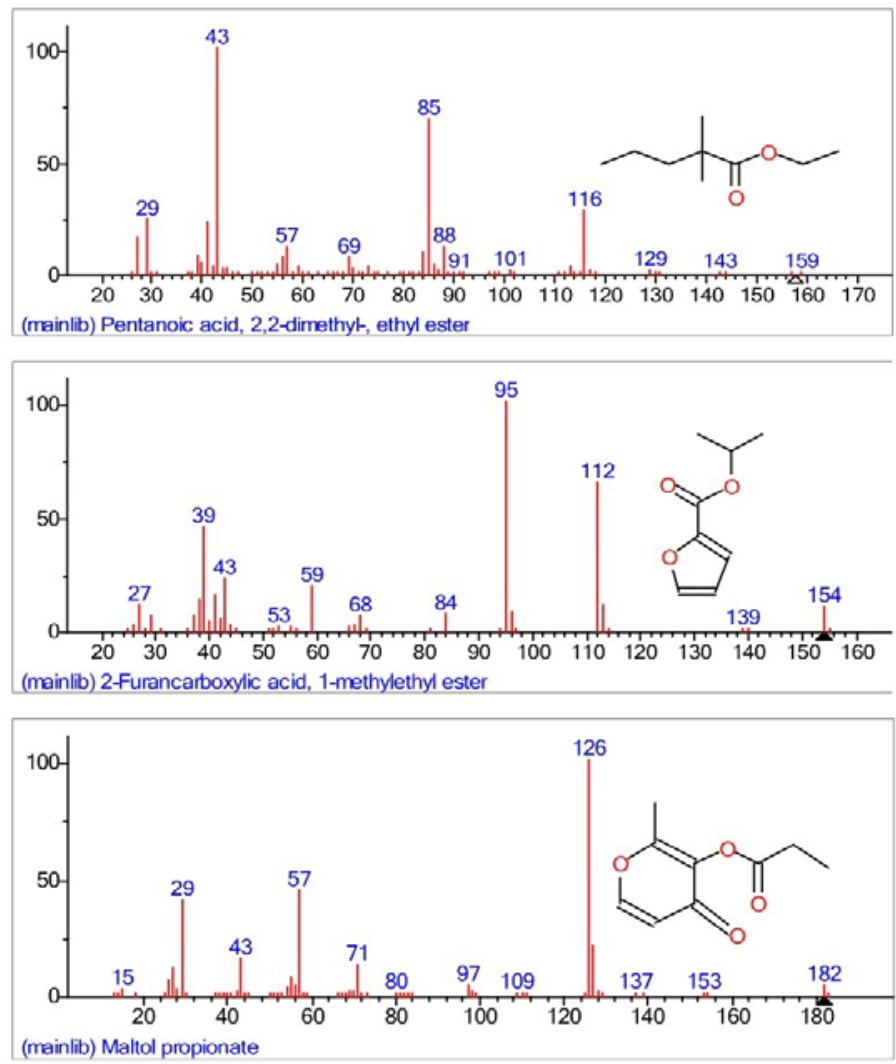

Fig. 3: 3(a), (b), (c): Mass spectrum of pentanoic acid, 2,2-dimethyl-ethy ester (3a), 2-Furancarboxylic acid, 1-methylethyl ester (3b), Maltol propionate (3c) [12]

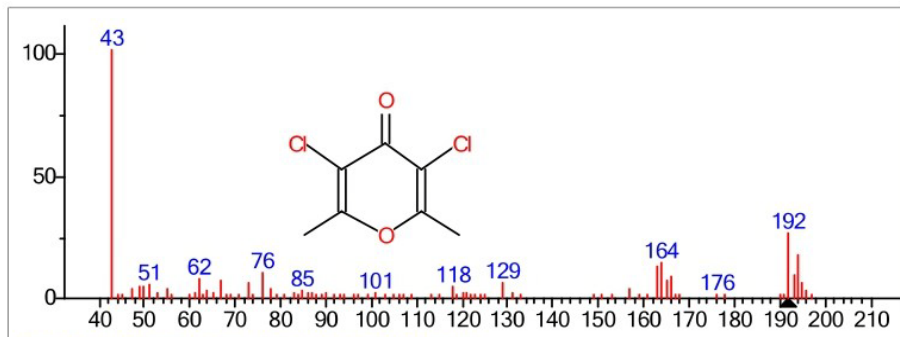
(mainlib) 4H-Pyran-4-one, 3,5-dichloro-2,6-dimethyl-
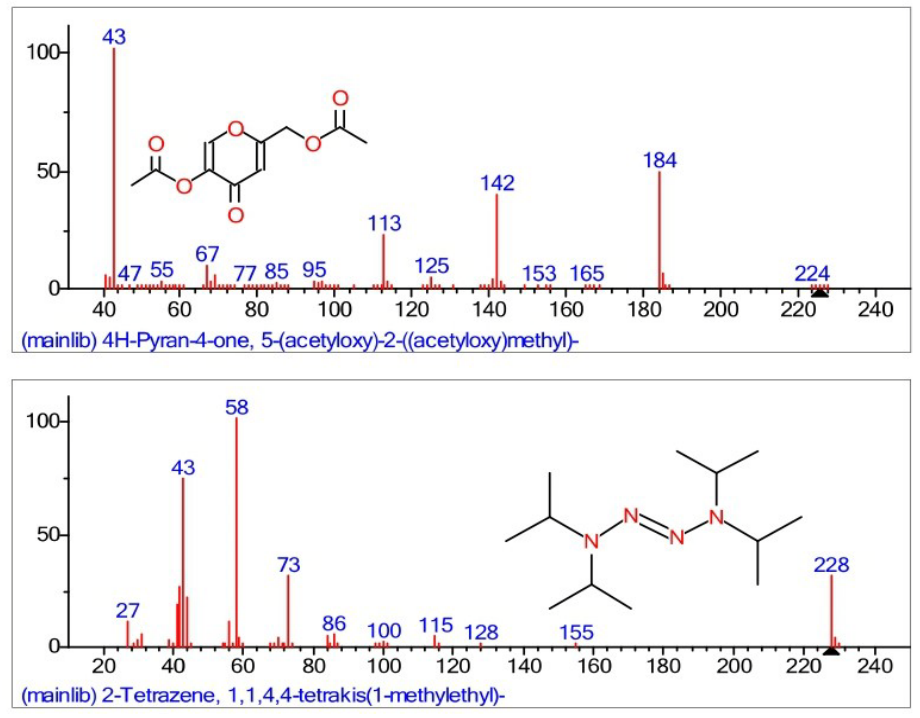

Fig. 4: 4(a), (b), (c): Mass spectrum of 4H-Pyran-4-one, 3,5-dichloro-2,6-dimethyl (4a), 4H-Pyran-4-one, 5-(acetyloxy)-2((acetyloxy)methyl)-(4b), 2-Tetrazene, 1,1,4,4-tetrakis(1-methyethyl)-(4c) 

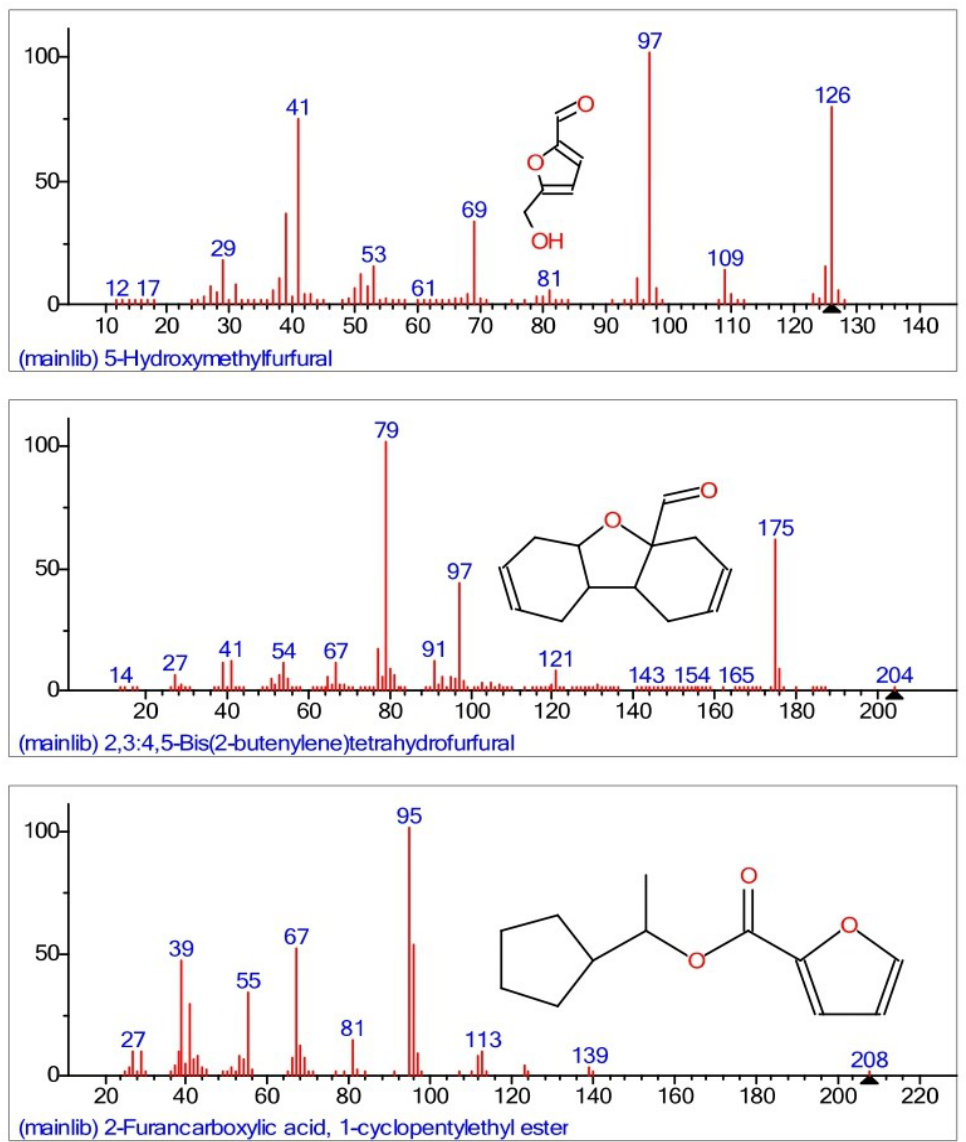

Fig. 5: 5(a), (b), (c): Mass spectrum of 5-Hydroxymethylfurfural (5a), 2,3;4,5-Bis(2-butenylene) tetrahydrofurfural (5b), 2Furancarboxylic acid, 1-cyclopentylethyl ester(5c) [12]
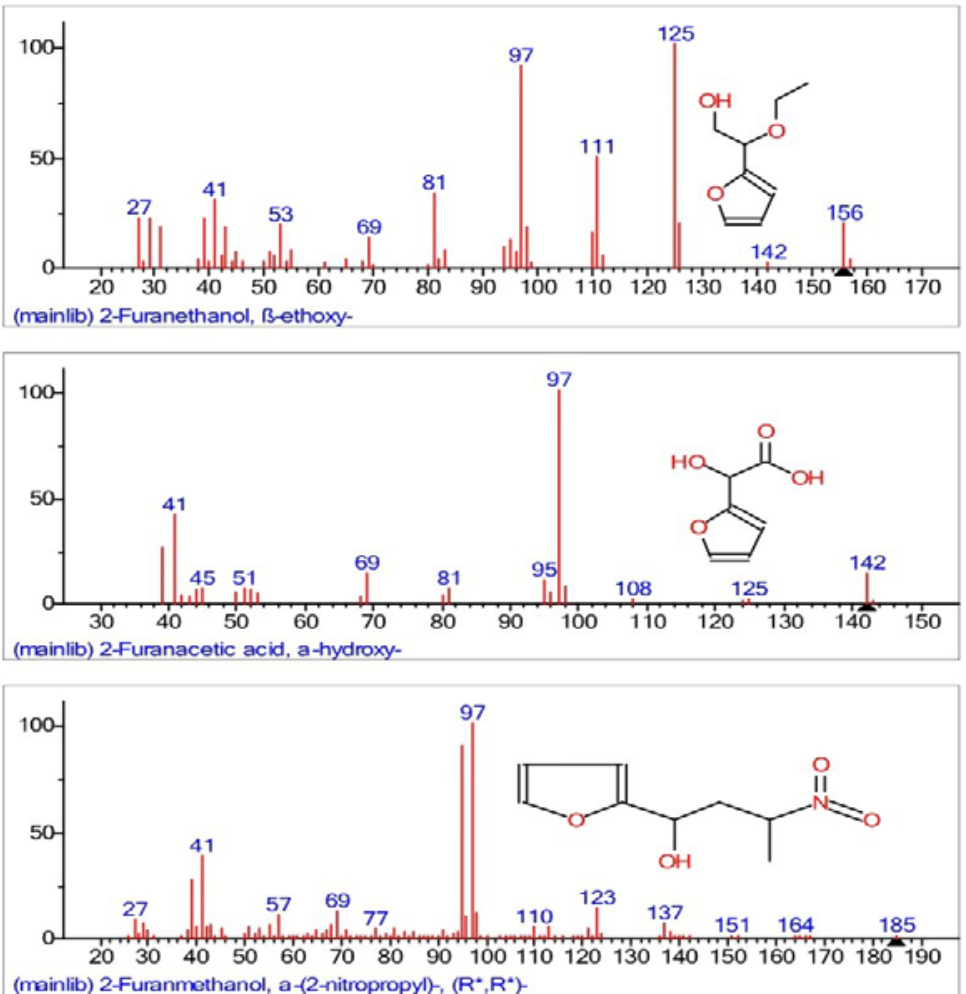

Fig. 6: 6(a), (b), (c): Mass spectrum of 2-Furanethanol, $\beta$-ethoxy-(6a), 2-Furanacetic acid, $\alpha$-hydroxy-(6b), 2-Furanmethanol, $\alpha$-(2nitropropyl)-,( $\left.R^{*}, R^{*}\right)(6 c)[12]$ 


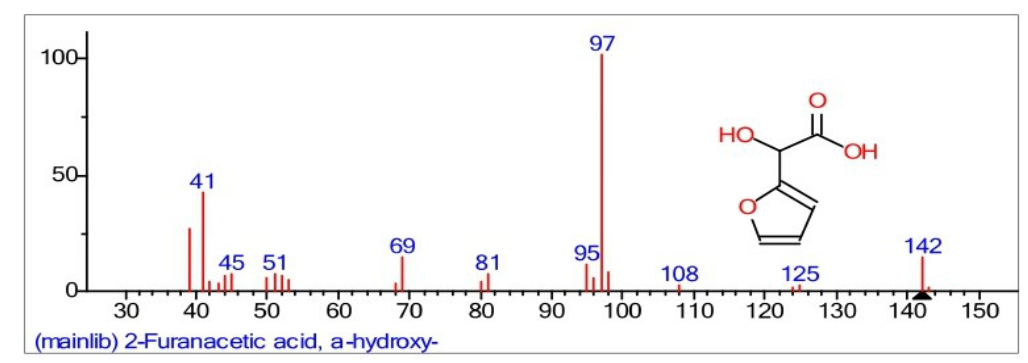

Fig. 7: Mass spectrum of 2-Furanacetic acid, $\alpha$-hydroxy [12]

\section{Mineral constituents}

OE contains calcium, magnesium, iron, zinc, copper [7], and potassium [14].

\section{Phytochemistry}

Ethanolic extract of OE contains alkaloids, carbohydrates, [5, 6, 15-17] fats, [5, 6, 15-17] oils, flavonoids, phenolics, tannins, steroids, saponins, [6, 15-17] proteins, [5, 6] betalains, [5, 6, 17] and Vitamin C. [5] Major constituents of $\mathrm{OE}$ are carbohydrates (glucose, sucrose, reducing hexose monosaccharide ie. Glucose and galactose), polyphenols (vannilic, syringic and protocatechuric phenolic acids), flavonoids (flavonoids and flavonone) and betalains (betacyanins type of color pigments). Saturated (palmitic acid) and unsaturated (eicosadienoic acid) fatty acids are found in OE [6]. Total sugars range from $12-17^{\circ}$ Brix and are mainly of the reducing type, with glucose being the predominant sugar and fructose being the second sugar imparting the fruit pulp its sweet taste. Preliminary analysis suggests that the external color of prickly pear fruits depends on the relative concentration of betacyanins which has the antioxidant potential [14].

\section{Toxicity profile}

In a study, the oral administration of crude extract exhibited no toxic effect on the external morphology and bodyweight of the mice [15]. No significant behavioral changes and signs and symptoms of toxicity were observed during the acute oral toxicity study implicating the sample is relatively safe at $20.0 \mathrm{ml} / \mathrm{kg}$. In long-term toxicity, $\mathrm{OE}$ fruit juice, even at a higher dose of $18.0 \mathrm{ml} / \mathrm{kg}$ administered for $60 \mathrm{~d}$, did not affect the parameters studied to a significant level in rats [18]. Protective effect of OE fruit juice and extract of Withania somnifera in lead acetate toxicity was studied and found that, administration of OE and Withania somniferafor a longer period may improve performance of broilers chickens as well as act as a protectant to organs [19].

\section{Reported pharmacological activities}

\section{Anti-oxidant activity}

Methanolic extract exhibited the highest antioxidant activity at $54.10 \%$ and the lowest antioxidant activity is exhibited by the hexanoic extract at $45.66 \%$ and the distilled water at $50.40 \%$ of antioxidant activity through Dimethyl sulfoxide (DPPH) assay [5]. IC50 values for extract of $\mathrm{OE}$ and Vitamin $\mathrm{C}$ was found to be 88.16 $\mathrm{g} / \mathrm{ml}$ and $62.83 \mathrm{~g} / \mathrm{ml}$ respectively [17]. Antioxidant property in aqueous extract of $\mathrm{OE}$ was determined by Phenolic content assay, Flavonoid content assay and Reducing power assay. Phenolic content was $12.315 \mathrm{mg} / \mathrm{gm}$, Flavonoid content was $56 \mathrm{mg} / \mathrm{gm}$ and reducing power was $30.5 \mathrm{mg} / \mathrm{gm}$ in aqueous extract of $\mathrm{OE}$. So aqueous extract of $\mathrm{OE}$ has poor antioxidant property. Mixture of compounds can lower antioxidant property in aqueous fraction of $\mathrm{OE}$, if any counteracting compounds were present in mixture. So pure compound isolation should be done in future to confirm antioxidant property of aqueous fraction of OE [20]. Hydro-alcoholic extract of $\mathrm{OE}$ fruit and quercetin showed the antioxidant activity as $38.14 \pm 1.07$ and $37.74 \pm 1.06 \%$ DPPH inhibition, respectively at 200 $\mu \mathrm{g} / \mathrm{ml}$ concentration [20].

\section{Cytotoxicity and anti-leukemic activity}

The cytotoxic evaluation showed a potent action against K562 (Human chronic myelocytic leukemia) cell line. Hydroalcoholic extract of the fruits of $\mathrm{OE}$ have persuasive antioxidant activity and promising antileukemic activity [17]. LC50 value of OE in aqueous fraction showed more cytotoxic activity than Tamoxifen. Since aqueous fraction of $\mathrm{OE}$ exhibited potent cytotoxic activity, it can be investigated for anticancer, pesticidal and antitumor properties in future [20]. The cytotoxic activity was measured by brine shrimp lethality bioassay. LC50 value of aqueous fraction of OE was $12.5 \mu \mathrm{g} / \mathrm{ml}$ in the brine shrimp lethality test. The fraction contained $16.47 \mathrm{mg}$ AAE/g of total phenolic content, $68.1 \mathrm{mg} \mathrm{AAE} / \mathrm{g}$ of total reducing power content and $35.88 \mathrm{mg} \mathrm{AAE} / \mathrm{g}$ total flavonoid content [21].

\section{Anti-diabetic}

In vitro antidiabetic activity of hydroalcoholic extract of $\mathrm{OE}$ fruit as well as quercetin at various concentrations were evaluated by using $\alpha$-amylase inhibition assay. Hydro-alcoholic extract of $\mathrm{OE}$ fruit and quercetin produced $\alpha$-amylase inhibition up to $54.68 \pm 0.11$ and $54.64 \pm 0.20 \%$, respectively, at $500 \mu \mathrm{g} / \mathrm{ml}$ concentration [16]. Effect of $\mathrm{OE}$ fruit juice and quercetin administration on alteration of glucose level, lipid profile, hyperalgesic response and spontaneous motor activity in diabetic rats were evaluated. Administration of $\mathrm{OE}$ and quercetin for $28 \mathrm{~d}$ has significantly lowered blood glucose level in diabetic rats. Upon glucose tolerance test, the glucose levels in rats of different treatment groups were significantly increased at 30 and $60 \mathrm{~min}$ after oral glucose load. However, glucose levels of diabetic rats treated with $\mathrm{OE}$ fruit juice and quercetin alone and in combination or Glibenclamide were significantly lowered at the end of $120 \mathrm{~min}$ [22].

\section{Complications of diabetes}

Betanin attenuated diabetic kidney injury by significantly inhibiting proteinuria, blood glucose, serum creatinine and BUN levels and restored antioxidant enzyme activities in kidney tissue. Histological studies exhibited that betanin treatment reduced the glomerular surface area, glomerulosclerosis and tubulointerstitial fibrosis. Furthermore, betanin modulated mRNA and protein expression of TGF- $\beta$, type IV collagen, $\alpha$-SMA and E-cadherin in kidney. The results conclude that betanin can effectively suppress renal fibrosis in DN, and may slow down the progression to end-stage renal disease by regulating TGF- $\beta$ signal pathway [13].

\section{Radioprotective activity}

The modulatory effect of OE stem extract was studied in Swiss albino mice at two doses i.e. 6 Gy and 8 Gy of gamma radiation in the presence (experimental) or absence (control) of OE extract (10 $\mathrm{mg} / \mathrm{kg}$ body wt.) to observe blood glucose level alterations. The glucose level was scored almost constant in the control group (without any treatment) on day 1, 15 and 30 post radiation, and increased in gamma radiation treated mice group, whereas a recovery pattern was recorded in experimental animals (in only plant extract treated and plant extract with radiation treated mice's groups) and a normal value was achieved by at 30th day after dose level [23]. Similar modulatory effect of OE stem extract was studied to observe blood cholesterol level alterations. Cholesterol level was estimated by the modified method of Roeschlau et al., 1974, using kit, at days 1,15 , and 30 post radiation. The cholesterol level was found almost constant in the control group (without any treatment), increased in gamma radiation-treated group and decreased in only plant extract-treated group, whereas radiation-induced hypercholestremia was reduced by plant extract treatment in 
experimental animals (in plant extract with radiation-treated group), a normal level was achieved by day 30 post-treatment. Hence, $\mathrm{OE}$ is beneficial to control radiation-induced hypercholestremia [24]. OE's potential to remove toxins induced by whole body exposure to Co60 gamma rays (6Gy) was tested. OE (10 $\mathrm{mg} / \mathrm{kg}$ body weight) was given orally to mice, before whole body irradiation and GOT activity was studied in their kidney at $1,3,5,10,15$ and 30 post treatment. Whole body gamma ray exposure increases GOT activity in the kidneys also. In OE pretreated animals this increase was significantly lesser and early recovery was observed. Both ethanolic and acetonic extracts were able to reduce gamma radiation induced increase significantly and almost equally [25]. The modulatory effect of OE stem extract was studied in Swiss albino mice at dose 6 Gy of gamma radiation. At days 1,15 and 30 post-irradiations, there was no variation in RBC and WBC counts including hemoglobin content in the control group (without any treatment); but significantly decreased in 6 Gy gamma irradiation treated group IV, whereas a recovery pattern was recorded in experimental animals of Group II (OE extract $10 \mathrm{mg} / \mathrm{kg}$ ) and Group III (OE extract $10 \mathrm{mg} / \mathrm{kg}$ and 6Gy gamma irradiation dose) and a normal value of hematological parameters were regained by day 30 post-treatment with plant extracts as compared to radiation group with some variations [26].

\section{Broncho-dilatory activity}

The broncho-dilatory properties were evaluated using bronchospasm induced by acetylcholine and histamine, anticholinergic action on isolated rat ileum, and antihistaminic action on isolated guinea pig ileum. Broncho-dilatory effect of fruit juice was dose dependent against spasm induced by acetylcholine and histamine. O. elatior Mill. Fruits possess a significant inhibitory effect on rat and guinea pig ileum contraction through antihistaminic and antimuscarinic action. Betacyanin, an active principal compound in prickly pear, may be responsible for the action [27].

\section{Mast cell stabilization activity}

The Opuntia fruit juice (OFJ) $(10-200 \mu \mathrm{l} / \mathrm{ml})$ was studied for the effect on sensitized rat peritoneal mast cell degranulation induced by immunological (egg albumin), and nonimmunological (compound 48/80) stimuli and compared with that of the reference standard, sodium cromoglycate and ketotifen $(10 \mu \mathrm{g} / \mathrm{ml})$. The OFJ exhibited significantly $(\mathrm{P}<0.001)$ concentration dependent inhibition of mast cell degranulation. IC50 value of OFJ was found 12.24 and $18 \mu \mathrm{l} / \mathrm{ml}$ for immunological and nonimmunological induced mast cell degranulation, respectively [28].

\section{Analgesic and anti-inflammatory activity}

Writhing and tail-immersion tests were carried out to evaluate analgesic action, while the carrageenan-induced paw edema and neutrophil adhesion tests were conducted in Albino wistar rats to assess anti-inflammatory action. ED50 values of the fruit juice in writhing, tail immersion, and paw edema test were $0.919,2.77$, and $9.282 \mathrm{ml} / \mathrm{kg}$, respectively. The fruits of OE produced analgesic and anti-inflammatory action in a dose-dependent manner [29].

\section{Reversible fertility activity}

The methanolic extract was administered through oral route $(300$, $900 \mathrm{mg} / \mathrm{kg}$ body weight) to male rats for 30 and $60 \mathrm{~d}$, and fertility was assessed by analyzing spermatogenesis, sperm count and testosterone levels. Reversibility of fertility suppression was studied by withdrawal of treatment for two weeks and mating with normally cycling virgin females. Sperm count and motility were markedly reduced in both the groups, without commensurate decline in serum testosterone levels and testicular hydroxysteroid dehydrogenase (HSDH) activity. Fertility of the treated rats was suppressed when mated with normally cycling virgin female rats without affecting libido. Withdrawal of treatment for two weeks restored the sperm count, testicular HSDH activity, serum testosterone levels and fertility. The methanolic extract of the fruit of $\mathrm{OE}$ produces reversible male antifertility effect without affecting the testosterone levels and libido. [30] Contraceptive efficacy of OE fruits on male mice was studied and $\mathrm{OE}$ proved to be an effective contraceptive agent to regulate male fertility [31].

\section{Hematinic activity}

Hematinic effect of $\mathrm{OE}$ fruit on mercuric chloride $(\mathrm{HgCl} 2)$ induced anemia in rats was assessed and significant increase in the hemoglobin content, serum ferritin level and serum TIBC level was noted. Test drug OE fruit Swarasa (juice) reversed anemia induced by $\mathrm{HgCl} 2$ in a dose-dependent manner $[32,33]$. The hematinic activity of OE fruit juice on phenylhydrazine (PHZ)-induced anemic rats was evaluated. The $\mathrm{Hb} \%$ was significantly increased $(\mathrm{P}<0.05)$ in fruit juice treated rats, compared to the standard. This might be due to increased erythropoiesis and/or antioxidant property of betacyanin $[34,35]$. In a study on carboplatin induced anemia, Opuntia Swarasa at dose levels 1.8 and $3.6 \mathrm{ml} / \mathrm{kg}$ showed a good percentage of recovery in haemoglobin, $19.66 \%$ and $36.99 \%$ respectively, in TRBC, $38.53 \%$ and $47.69 \%$ respectively, which is higher than the standard carboplatin treated group [36].

In an open labeled clinical trial on geriatric population diagnosed with anemia, administration of $\mathrm{OE}$ fruit juice $(20 \mathrm{ml}$ twice daily before meals for $30 \mathrm{~d}$ ) was found effective in the management of anemia by significantly relieving the cardinal symptoms like giddiness, pallor, dyspnoea on exertion, weakness and cramps in calf muscles. Significant increase in $\mathrm{Hb} \%$ was also reported [37]. In an open labelled randomized controlled clinical trial, fruit juice of $\mathrm{OE}$ was found effective in the treatment of iron deficiency anemia as it increased the hemoglobin, TRBC levels in blood along with providing relief in cardinal symptoms like pallor, general weakness, periorbital edema [38]. In a comparative clinical trial between beetroot capsule and prickly pear (PP) capsule, there was increase in hemoglobin (Hb) percentage and total RBC in both treatments after $30 \mathrm{~d}$. On day 60 , mean $\mathrm{Hb}$ content and total RBC were significantly increased in BR group and in PP group (11.14 $\pm 0.32 \mathrm{gm} \%$; $9.25 \pm 0.391012 / \mathrm{l}$, $\mathrm{p}<0.001$ ) [39].

\section{Anti-arthritic}

A study reports anti-arthritic potential of opuntioside-I opuntiol, and its gold and silver nanoparticles (NPs) against Complete Freund's Adjuvant (CFA)-induced arthritic rats. The mechanistic studies were performed targeting Toll Like receptors (TLRs), TLR-2 and TLR-4 and cytokines (IL-1 $\beta$ and TNF- $\alpha$ ) expressions to validate their antiinflammatory and immuno-modulatory response. The nanoformulations were successfully characterized employing Atomic Force Microscopy (AFM) and Dynamic Light Scattering (DLS) analysis. Opuntiol and opuntioside (OP and OPG: 10,50 and 100 $\mathrm{mg} / \mathrm{kg}$ ) and opuntiol-coated silver and gold NPs (OP-AgNPs and OPAuNPs: $0.5,1$ and $3 \mathrm{mg} / \mathrm{kg}$ ) treatments in arthritic rat have shown minimal arthritic score exhibiting mild to moderate articular changes and tissue swelling in ankle joints. Radiographic examination reveals significant reduction in synovitis with improvement in joints degenerative changes in the presence of aforementioned treatments [40].

\section{Antimicrobial activity}

Antimicrobial activities were tested by using agar diffusion method, against six human pathogenic microorganisms, including Bacillus subtilis, Bacillus cereus, Staphylococcus aureus, Staphylococcus saprophyticus, Enterobacter aerogenes, and Micrococcus luteus while including $5 \%$ (DMSO) as a negative control. The highest antimicrobial activity was found against $S$. saprophyticus at the minimum concentration of $0.75 \pm 0.43 \mathrm{mg} / \mathrm{ml}$, the following was against $M$. luteus at the minimum concentration of $1.50 \pm 0.00 \mathrm{mg} / \mathrm{ml}$. This extract showed the minimum concentration inhibited against other microorganisms at $3.00 \mathrm{mg} / \mathrm{ml}$ [41].

\section{CONCLUSION}

Opuntia elatior Mill (Cactaceae) is extensively used for nutritional and medicinal purposes in various parts of the world like Southern America, Africa, Indonesia, India. In India, its availability and utility are more in the Saurashtra region of Gujarat state. Fruit being the main part used as food and medicine, is rich in carbohydrates, phenolics, flavonoids, vit $\mathrm{C}$ and betalains which are attributable for the wide array of its pharmacological actions. It is reported safe for internal use in a dose dependent manner. The fruit as a whole as well as the extract possesses biological activities like anti-oxidant, anti-leukemic, 
broncho-dilatory, mast cell degranulating, radio-protective, contraceptive, reversible anti-fertility, hematinic, anti-diabetic, analgesic and anti-inflammatory, anti-arthritic and anti-microbial activity. A detailed insight into the phytochemistry and pharmacological properties has been provided in the review. Further study on the mechanism of action of the pure compounds of the species are required for the better understanding of the complex pharmacological activities. Studies on female reproductive toxicity can be attempted in the future. Clinical data on pharmacology is limited. Hence, clinical studies can be taken up on various biological activities.

\section{SOURCES OF FUNDING}

Nil

\section{AUTHORS CONTRIBUTIONS}

All the authors have contributed equally.

\section{ACKNOWLEDGEMENT}

Authors are thankful to Director, ITRA, for providing Library and other facility to carry our research work.

\section{CONFLICT OF INTERESTS}

Authors declare that there is no conflict of interest.

\section{REFERENCES}

1. Hazarika TK, Lalramchuana L, Nautiyal BP. Studies on wild edible fruits of Mizoram, India used as ethno-medicine. Genet Resour Crop Evol. 2012;59(8):1767-76. doi: 10.1007/s10722012-9799-5.

2. Krishna H, Saroj PL, Maheshwari SK, Singh RS, Meena RK, Chandra R. Underutilized fruits of arid and semi-arid regions for nutritional and livelihood security. International Journal of Minor Fruits. Med Aromat Plants. 2019;5(2):1-14.

3. Pasiecznik N. Invasive species compendium. France: Agroforestry Enterprises; 2019.

4. Prajapati S, Acharya RN. Opuntia elatior Mill. (Nagaphani): a review on its ethnobotany, phytochemical and pharmacological properties. Ann Ayurvedic Med. 2015;4:3-4.

5. Patel KN, Ishnava KB Asao $\mathrm{T}$, Asaduzzaman $\mathrm{M}$, editors. Evaluation of nutritional and medicinal properties of Opuntia elatior mill. Phytochemicals-source of antioxidants and role in disease prevention. IntechOpen; 2018.

6. Bhatt MR, Sheth DD, Khara J. Nutritional potential and stability of Opuntia elatior Mill. fruit juice [dissertation]. Baroda: Maharaja Sayajirao University; 2012.

7. Roghelia V, Panchal J. Physicochemical characteristics of cactus pear fruits. J Pharm Chem Biol Sci. 2016;4(1):119-25.

8. Patel H, Prajapati S, Acharya R, Harisha CR, Shukla V. A preliminary phyto-pharmacognostical evaluation of Opuntia elatior mill. (Nagaphani or Hathlo-thore) fruit. Int J Ayurvedic Med. 2015;6(4):310-6.

9. Bhatt MR, Nagar PS. Evaluation of physicochemical property and fatty acid composition of Opuntia elatior seed oil. J Prof Assoc Cactus Dev. 2013;15:13-9.

10. Ganguly AK, Govindachari TR, Mohamed PA. Structure of opuntiol, a constituent of Opuntia elatior. Tetrahedron. 1965;21(1):93-9. doi: 10.1016/S0040-4020(01)82206-7.

11. Halimfanezi L, Rusdi AR. A review: analysis of betacyanin levels in various natural products. Asian J Pharm Res Dev. 2020;8(5):89-95.

12. Phytochemical and GC-MS analysis of the ethanol fruit extract of Opuntia elatior. Open Database; 2021. Available from: https://fdocuments.in/document/chapter-ii.pdf. [Last accessed on 22 Sep 2021]

13. Sutariya B, Saraf M. Betanin, isolated from fruits of opuntia elatior mill attenuates renal fibrosis in diabetic rats through regulating oxidative stress and TGF- $\beta$ pathway. J Ethnopharmacol. 2017;198:432-43. doi: 10.1016/ j.jep.2016.12.048, PMID 28111218.

14. Chauhan SP, Navin S, Suhagia B, Mardia RB. Phytochemical screening of fruits of Opuntia elatior mill. AJPTR 2013;3(2):1-16.
15. Chamundaiah RM, Shivabasavaiah KH. Ethnomedicinal value of Opuntia elatior fruits and its effects in mice. J Pharm Res. 2012;5(8):4554-8.

16. Kotadiya CR, Patel UD, Chauhan VB, Patel HB, Modi CM, Bhatt PR. In vitro antioxidant and antidiabetic activity of hydroalcoholic extract of Opuntia elatior fruit as well as quercetin. Int J Sci Environ Technol. 2017;6(2):1028-35.

17. Itankar P, Acharya S, Arora S, Thakre P. OA01.47. Phytochemical study and evaluation of antileukemic activity of ripe fruit of opuntia elatior. Mill Ancient Sci Life. 2012;32(5):47. doi: 10.4103/0257-7941.112018.

18. Sanyal SK, Acharya RN, Nariya MK, Gamit R. Toxicological study of Opuntia elatior Mill., fruit (ripen) juice: A folklore medicinal plant. Int J Green Pharm. 2015;9(4):39-44.

19. Shah TM, Patel UD, Nimavat VR, Fefar DT, Kalaria VA, Javia BB, Savsani HH, Kotadiya CR. Toxico-pathological studies on experimentally induced lead acetate toxicity in broiler chickens with protective effect of opuntia elatior and withania somnifera. Asian J Anim Sci. 2016;11(1):33-9. doi: 10.15740/HAS/TAJAS/11.1/33-39.

20. Alam S. Cytotoxic and Antioxidant activity in aqueous fraction of Opuntia elatior extract [dissertation]. Dhaka: East-West University; 2011.

21. Islam S. In vitro pharmacological investigations of dichloromethane fraction of Opuntia elatior, Dhaka; 2015. Available from: http://dspace.edubd.edu/handle/2525.1690. [Last accessed on 10 Sep 2021]

22. Kotadiya C, Patel UD, Modi CM, Patel HB, Kalaria VA, Chauhan VB. Effect of Opuntia elatior fruit juice and quercetin administration on glucose level, lipid profile, hyperalgesic response and spontaneous motor activity in diabetes rats. The Pharm Innov J. 2017;6(8):150-5.

23. Poonia K, Sharma J. Effect of Opuntia elatior on alteration in blood glucose level induced by gamma radiation in mice. Int Res J Pharm. 2019;10(6):43-7. doi: 10.7897/2230-8407.1006201.

24. Poonia K, Sharma J. Effect of Opuntia elatior on cholesterol level alterations induced by gamma radiations in swiss albino mice. Asian J Pharm Clin Res. 2019;12(3):578-81.

25. Poonia K, Sharm J. Effect of Opuntia elatior on alteration in glutamic oxaloacetic transaminase activity induced by gamma radiation in swiss albino mice. Int J Lifescience Pharm Res. 2020;10(4):90-5.

26. Poonia K, Sharma J. Radioprotective effect of Opuntia elatior on blood of swiss albino mice. IJPSR. 2019;10(5):2306-14.

27. Chauhan SP, Sheth NR, Suhagia BN. Evaluation of bronchodilatory properties of fruits of Opuntia elatior mill. Egypt Pharmaceut J. 2015;14(1):44-9. doi: 10.4103/1687-4315.154717.

28. Chauhan SP, Sheth NR, Suhagia BN. Effect of fruits of opuntia elatior mill on mast cell degranulation. J Pharm Bioallied Sci. 2015;7(2):1569. doi: 10.4103/0975-7406.148779, PMID 25883521.

29. Chauhan SP, Sheth NR, Suhagia BN. Analgesic and antiinflammatory action of opuntia elatior mill fruits. J Ayurveda Integr Med. 2015;6(2):75-81. doi: 10.4103/0975-9476.159025, PMID 26166996.

30. Chamundaiah RM, Shivabasavaiah ST. Fertility suppression by the fruit extract of Opuntia elatior in the male rat: possible extragonadal action. J Endocrinal Reprod. 2014;18(1):7-16.

31. Chamundaiah RM, Krishna Ram H, Shivabasavaiah. Reproductive toxicity of opuntia fruit extract in male swiss albino mice. Int J Adv Biol Res. 2013;3(3):464-9.

32. Patel H, Prajapati S, Ranade A, Acharya RN, Nariya MK. Evaluation of the haematinic activity of Opuntia elatior Mill. fruit. Indian J Nat Prod Resour. 2018;9(1):39-46.

33. Chauhan SP, Sheth NR, Suhagia BN. Haematinic evaluation of fruits of opuntia elatior mill. on mercuric chloride induced anemia in rats. Int J Res Ayurveda Pharm. 2014;5(1):115-22. doi: 10.7897/2277-4343.05124.

34. Chauhan SP, Sheth NR, Suhagia BN. Hematinic effect of fruits of Opuntia elatior mill. on phenylhydrazine-induced anemia in rats. Ayu. 2015;36(2):208-13. doi: 10.4103/09748520.175549, PMID 27011725.

35. Vadhvana V. Haematinic activity of Nagaphani (Opuntia elatior Mill.) on Haemolytic anemia in Albino rats. Jamnagar: GAU; 2019. 
36. Prajapati S. A pharmacological and pharmaco-therapeutical evaluation of fruit of Nagaphani (Opuntia elatior mill.) on Pandu [thesis]. Jamnagar: Gujarat Ayurved University; 2016.

37. Prajapati S, Ranade A, Acharya R, Goyal M. Clinical evaluation of Opuntia elatior Mill. (Nagaphani) fruit in the management of Pandu with special reference to Geriatric anemia. Glob J Res Med Plants Indigenous Med. 2016;5(4):114-20.

38. Prajapati SM, Anand S, Acharya RN, Goyal M. Effect of Opuntia elatior mill. (Nagaphani) in the management of Pandu Roga w.s.r. to iron deficiency anaemia; an open labelled randomized standard controlled clinical trial. Ayu. 2021;4(2):87-97.

39. Chauhan S, Gopani T, Suhagia B, Gupta S, Patel K, Patel M. Clinical evaluation of Beet root and prickly pear in the management of anemia: an observational study. J Ayurveda Med Sci. 2018;2(4):274-7. doi: 10.5530/jams.2017.2.30.

40. Roome T, Aziz S, Razzak A, Aslam Z, Lubna JKS, Jamali KS, Sikandar B, Fatima T, Abidi L, Imran M, Faizi S, Shah MR. Opuntioside, opuntiol and its metallic nanoparticles attenuate adjuvant-induced arthritis: novel suppressors of toll-like receptors-2 and-4. Biomed Pharmacother. 2019 April;112:108624. doi 10.1016/j.biopha.2019.108624, PMID 108624.

41. Singchai B, Pongputthachat D, Daengkhwanthong U. Antioxidant and antimicrobial activities of Opuntia elatior fruit. Science and genetic engineering. The 55th academic conference of kasetsart university; 2021. p. 240-5. Available from: https://agris.fao.org/agrissearch/search.do?recordID=TH2018000395. [Last accessed on 30 Dec 2021]. 